\title{
Incident Precipitation Partitioning: Throughfall, Stemflow and Canopy Interception in Eucalyptus dunnii Stand
}

\author{
Dione Richer Momolli ${ }^{1}$, Mauro Valdir Schumacher ${ }^{1}$, Márcio Viera ${ }^{1}$, Aline Aparecida Ludvichak ${ }^{1}$, \\ Claudiney do Couto Guimarães ${ }^{1} \&$ Huan Pablo de Souza ${ }^{1}$ \\ ${ }^{1}$ Department of Forest Sciences, Federal University of Santa Maria, Santa Maria, Rio Grande do Sul, Brazil \\ Correspondence: Dione Richer Momolli, Laboratório de Ecologia Florestal, Federal University of Santa Maria, \\ Santa Maria, RS., Brazil. Tel: 55-559-9727-1859. E-mail: dionemomolli@gmail.com
}

Received: January 11, 2019

Accepted: February 17, 2019

Online Published: April 15, 2019

doi:10.5539/jas.v11n5p372

URL: https://doi.org/10.5539/jas.v11n5p372

\begin{abstract}
Atmospheric deposition is responsible for the ions input, which may be due to dust and aerosols and rainfall. During rainfall a portion is intercepted by the tree canopy and returned to the atmosphere by evapotranspiration, another part crosses the forest canopy called throughfall and stemflow. The objective of the study was to quantify incident rainfall partitioning into throughfall, stemflow and canopy interception in a Eucalyptus dunnii stand in southern Brazil. Four plots of $20 \mathrm{~m} \times 21 \mathrm{~m}$ were demarcated. The rainfall consists 3 rain collectors in an open area. The throughfall consisted 3 collectors per plot in the line, interlining and diagonal positions of the trees. The stemflow consisted in the installation of three systems per plot formed by a hose in the trunk of the tree that leads the solution to a reservoir. The adjustment of the throughfall, stemflow and canopy interception in function of the incident precipitation was of $99 \%, 90 \%$ and $52 \%$. As the volume of rainfall increases, the coefficient of variation decreases. The annual rainfall was $1903 \mathrm{~mm}$, with a canopy interception average of $8.9 \%$.
\end{abstract}

Keywords: regressions, hydrology, seasonality

\section{Introduction}

The understanding of rainwater partitioning is important for the hydrological balance, especially when dealing with large areas covered with vegetation (Rodriguez Suarez et al., 2014). One of the consequences of large areas being forested is the fact that a portion of the precipitation does not reach the soil. The fast-growing Eucalyptus sp genus has caused controversy regarding its water consumption and its impact on a microbasin (Jackson et al., 2005). Comparing two paired micro-basins, Reichert et al. (2017) concluded that the interception by canopy is greater in eucalyptus area than in natural grassland area and pasture

During rain events, part of the rainwater that reaches the canopy is intercepted and the atmosphere will be returned later (Llorens \& Domingo, 2007). The water that crosses the forest canopy and directly reaches the litter is called the throughfall (Navar, 2011). Another part descends through leaves, branches and flows through the trunk supplying with water and nutrients the roots (Zhang et al., 2016; Johnson \& Lehmann, 2006).

Some studies do not consider intercept by the canopy in their modeling, or often consider a generic value and low representativity (Chaffe et al., 2010). In regions of tropical climate, the percentage that is intercepted and returned to the atmosphere may be even more significant (Savenije, 2004).

The interception of water is influenced by biotic characteristics such as morphophysiological, height, contact surface of different plant species (Keim et al., 2006) and abiotic factors such as intensity, quantity, duration and size of the raindrop (Calder, 1999; Sulínski et al., 2001). Many factors such as vegetation cover, plant density, relative humidity, temperature, solar radiation, precipitation intensity, direction and wind speed, interfere with the evaluation of the interception by the canopy (Gerrits \& Savenije, 2011; Bulcock \& Jewitt, 2012; Levia \& Frost, 2006; Hörmann et al., 1996), besides the seasonal variation (Salehi et al., 2016). As the rainfall and the degree of canopy closure increases, there is a decrease in the coefficient of variation for the throughfall (Carlyle-Moses et al., 2014; A. Zimmermann \& B. Zimmermann, 2014; Thomaz \& Antonelli, 2015).

Several studies point to the importance of studies of throughfall and stemflow under a biogeochemical aspect (Staelens et al., 2006; Fan et al., 2015), in addition they provide water to the plants (Bouillet et al., 2002). It is known that both the throughfall and the stemflow have great spatial variation depending on the forest type 
(Llorens \& Domingo, 2007; Mululo Sato et al., 2011), however the variation in the stemflow is more pronounced (Levia et al., 2010).

In Brazil the area occupied by Eucalyptus plantations exceeds 5.67 million hectares and an average rotation of 4.8 years (IBA, 2017). Therefore, the objective of the present work was to quantify the incident precipitation, throughfall, stemflow and canopy interception in a Eucalyptus dunnii stand in Southern Brazil.

\section{Method}

\subsection{Characterization of the Experimental Area}

The study was conducted in Alegrete, state of Rio Grande do Sul, southern Brazil, under the central geographic coordinates of $29^{\circ} 47^{\prime} 10^{\prime \prime} \mathrm{S}$ and $55^{\circ} 17^{\prime} 30^{\prime \prime} \mathrm{W}$ (Figure 1). The experiment is located in a watershed with total area of 340.7 ha. About $31 \%$ of the area is for conservation, the remaining $69 \%$ is occupied by stands of Eucalyptus sp., being $23.4 \%$ of the total area covered by the species Eucalyptus dunnii. The stand of seminal origin was implanted with spacing $2.5 \mathrm{~m} \times 3.0 \mathrm{~m}$, with an initial density of 1427 trees per hectare. At the time of the study, the trees were between 84 and 96 months old ( 7 to 8 years respectively).

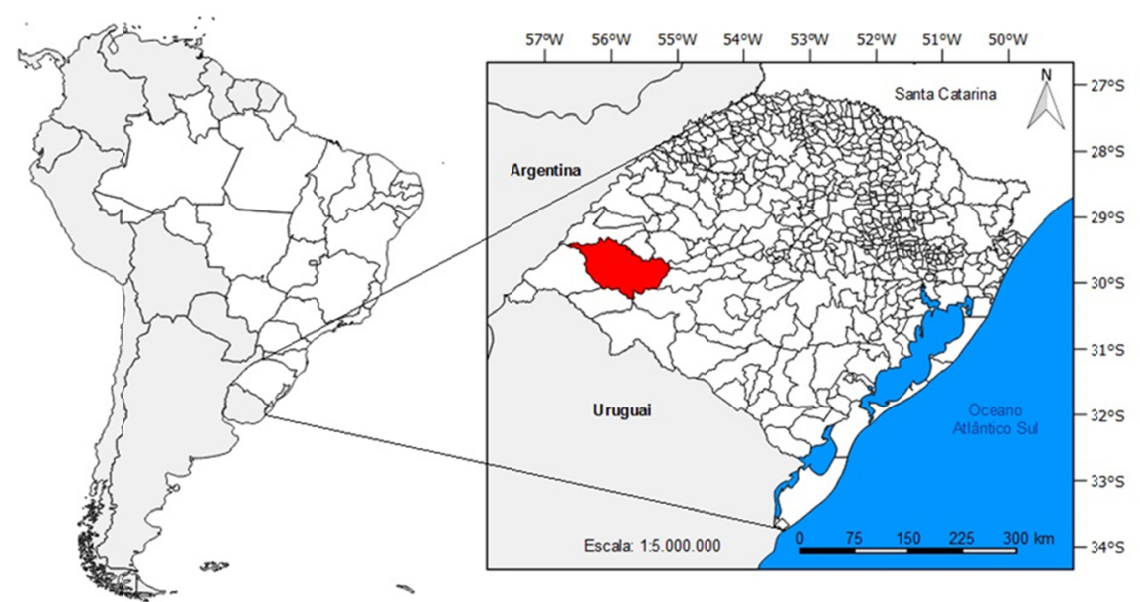

Figure 1. Location of the experimental area in Alegrete-RS, Brasil

Figure 2 shows the climatic diagram based on the Alegrete-RS meteorological station. The species Eucalyptus dunnii, is still classified with a medium climatic aptitude for the region of Alegrete (Flores et al., 2016).

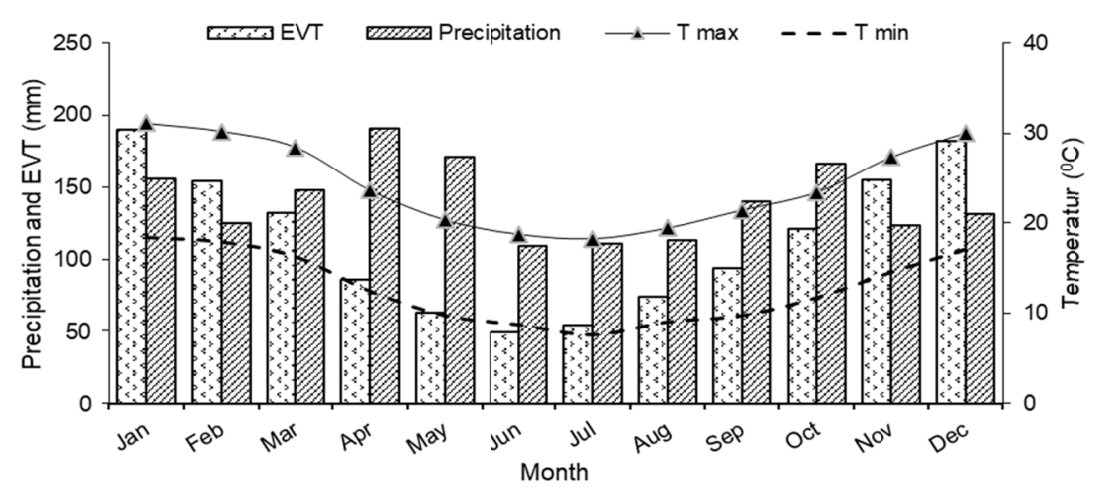

Figure 2. Climatic diagram of the Alegrete-RS. (Average values between the years 1985-2015 Agritempo, 2018). EVT $=$ evapotranspiration

The climate of the region is of the wet tempered sub-type Cfa. The variety "Cfa" is characterized by rainfall during all months of the year and has the temperature of the hottest month exceeding $22{ }^{\circ} \mathrm{C}$, and that of the coldest month exceeding $3{ }^{\circ} \mathrm{C}$. The summers can present a period of drought, with average annual temperature of $18.6^{\circ} \mathrm{C}$ and average annual rainfall of $1747 \mathrm{~mm}$ (Alvares et al., 2014). 


\subsection{Measurement of Precipitation, Throughfall, Stemflow a Canopy Interception}

The monitoring of rainfall $(\mathrm{P})$ occurred with the installation of 3 collectors with a diameter of $20 \mathrm{~cm}$ at $1.5 \mathrm{~m}$ from the ground level. They were allocated in a field area, distant about $50 \mathrm{~m}$ from the plots of the eucalyptus stand. Neoprene straps with galvanized steel wires were placed in order to avoid that they be used as perches for birds.

For the throughfall (Tf), 4 plots were demarcated inside the stand with dimensions of $20 \mathrm{~m} \times 21 \mathrm{~m}$. Then, 3 collectors with a diameter of $20 \mathrm{~cm}$ and height of uptake of $1 \mathrm{~m}$ of the soil level were distributed in the positions line, between line and diagonal of the trees in each of the plots.

The determination of the amount of the incident precipitation $(\mathrm{P})$ and throughfall $(\mathrm{Tf})$ in $(\mathrm{mm})$ was obtained by the following equation:

$$
\mathrm{P} \text { or } \mathrm{Tf}=(\mathrm{x} / 0.0314)
$$

where, $\mathrm{P}(\mathrm{mm})=$ incident precipitation, $\mathrm{Tf}(\mathrm{mm})=$ throughfall, $\mathrm{X}($ liters $)=$ water accumulated $0.0314\left(\mathrm{~m}^{2}\right)=$ catchment area.

The quantification of the stemflow occurred with the installation of reservoirs with capacity of 60 liters in 3 trees of average BHD (breast height diameter) per plot. A 1-inch diameter, longitudinally cut hose, spirally mounted near the tree trunk, allowed the water flowing through the trunk to be stored in the reservoirs.

For the calculation of stemflow, the expression used by Preuhsler et al. (2006) was used:

$$
\mathrm{Sf}=(\mathrm{V} / \mathrm{g}) \times(\mathrm{G} / \mathrm{A})
$$

where, $\mathrm{Sf}(\mathrm{mm})=$ precipitation $(\mathrm{mm}), \mathrm{V}=$ volume collected (liters) $\mathrm{g}=$ tree basal area $\left(\mathrm{m}^{2}\right) \mathrm{G}=$ basal area of trees in plot $\left(\mathrm{m}^{2}\right) \mathrm{A}=$ plot area $\left(\mathrm{m}^{2}\right)$.

The canopy interception was determined by the equation used by Lima (1976): The canopy interception is determined indirectly. Is the difference of the incident precipitation by the sum of the throughfall with the stemflow. Data were collected biweekly over 12 months:

$$
\mathrm{Ci}=\mathrm{P}-(\mathrm{Tf}+\mathrm{Sf})
$$

where, $\mathrm{Ci}(\mathrm{mm})=$ canopy interception, $\mathrm{P}(\mathrm{mm})=$ Incident precipitation, $\mathrm{Tf}(\mathrm{mm})=$ throughfall, $\mathrm{Sf}(\mathrm{mm})=$ stemflow.

\subsection{Statistics and Data Analysis}

Statistical analysis was performed using IBM SPSS 20.0. The analysis of variance was performed in the data, assuming a completely randomized design with 3 treatments (rain partitions) and 12 repetitions (months), and the Tukey test was performed to compare the means $(\alpha=0.05)$.

Regression equations were adjusted for throughfall, stemflow and canopy interception as a function of the incident precipitation variable. The distribution of the regression residues was then analyzed in order to validate the homogeneity of variance. The residues were presented in graphic form as a function of the variable analyzed.

The coefficient of variation (CV) is a well accepted statistical parameter (Zimmermann et al., 2007), and it was used to quantify the variability of the monthly rainfall indexes, as well as the influence of rainfall on the CV obtained:

$$
\mathrm{CV}=\partial / \Phi
$$

where, $\partial$ is the standard deviation of the collected volume and $\Phi$ is the volume average.

\section{Results and Discussion}

\subsection{Distribution of Incident Precipitation, Throughfall, Stemflow, Canopy Interception}

The annual precipitation was $1903 \mathrm{~mm}$, with a monthly average of $159 \mathrm{~mm}$. The month of September recorded the highest volume, $258 \mathrm{~mm}(\mathrm{p} \leq 0.05)$. April and August recorded the lowest volumes, 54 and $67 \mathrm{~mm}$ respectively, with no statistical difference between them (Table 1).

The measured throughfall was $1718 \mathrm{~mm}$, that is, $90.3 \%$ of the incident rain crossed the canopy and reached the forest floor. The month of September likewise differed statistically from the others, and recorded the highest volume, $255 \mathrm{~mm}$. The months of April and August did not differ statistically among themselves and accumulated the lowest indexes, 46 and $59 \mathrm{~mm}$ respectively. Evaluating the rainfall partition with Eucalyptus dunnii between 4 and 5 years of age, Dick et al. (2018) found an average of $91 \%$ for throughfall and $1 \%$ for stemflow. 
Table 1. Values of the incident precipitation (P), throughfall (Tf), stemflow (Sf), canopy interception (Ci) in (\%), for a Eucalyptus dunnii stand in the year 2015 in Alegrete-RS

\begin{tabular}{|c|c|c|c|c|}
\hline Month & $\mathrm{P}$ & $\mathrm{Tf}$ & $\mathrm{Sf}$ & $\mathrm{Ci}$ \\
\hline & \multicolumn{3}{|c|}{ 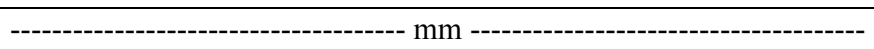 } & ------ \% ------ \\
\hline JAN & $121.0 \mathrm{e}^{*}( \pm 1.4)^{* *}$ & $102.5 \mathrm{~g}( \pm 1.0)$ & 0.5 ef $( \pm 0.0)$ & 11.9 \\
\hline FEB & $188.7 \mathrm{c}( \pm 5.3)$ & $162.2 \mathrm{e}( \pm 9.3)$ & $1.3 \mathrm{~cd}( \pm 0.2)$ & 10.4 \\
\hline MAR & $241.0 \mathrm{~b}( \pm 0.9)$ & $226.2 \mathrm{~b}( \pm 3.3)$ & $1.7 \mathrm{abc}( \pm 0.2)$ & 4.2 \\
\hline APR & $53.6 \mathrm{f}( \pm 0.7)$ & $46.0 \mathrm{~h}( \pm 0.7)$ & $0.2 \mathrm{f}( \pm 0.1)$ & 6.9 \\
\hline MAY & $190.7 \mathrm{c}( \pm 0.0)$ & $179.4 \mathrm{~d}( \pm 1.7)$ & $1.4 \mathrm{bcd}( \pm 0.6)$ & 5.2 \\
\hline JUN & $135.1 \mathrm{de}( \pm 7.9)$ & $108.1 \mathrm{~g}( \pm 6.4)$ & $1.0 \mathrm{de}( \pm 0.3)$ & 9.2 \\
\hline JUL & $119.0 \mathrm{~d}( \pm 0.0)$ & $104.5 \mathrm{~g}( \pm 3.0)$ & $1.0 \mathrm{de}( \pm 0.2)$ & 6.1 \\
\hline AUG & $66.8 \mathrm{f}( \pm 0.0)$ & $58.7 \mathrm{~h}( \pm 1.3)$ & $0.0 \mathrm{f}( \pm 0)$ & 9.2 \\
\hline SEP & 285.8 a $( \pm 5.4)$ & $254.5 \mathrm{a}( \pm 10.1)$ & $2.2 \mathrm{a}( \pm 0.2)$ & 7.9 \\
\hline OCT & $181.9 \mathrm{c}( \pm 3.8)$ & $155.1 \mathrm{e}( \pm 5.3)$ & $2.0 \mathrm{ab}( \pm 0.3)$ & 13.4 \\
\hline NOV & $140.1 \mathrm{~d}( \pm 0.5)$ & $124.7 \mathrm{f}( \pm 2.5)$ & $1.2 \mathrm{~cd}( \pm 0.2)$ & 8.6 \\
\hline DEC & $223.5 \mathrm{~b}( \pm 10.4)$ & $195.1 \mathrm{c}( \pm 13.8)$ & $1.7 \mathrm{abc}( \pm 0.2)$ & 14.1 \\
\hline Total & 1903.1 & 1718.1 & 14.5 & 8.9 \\
\hline
\end{tabular}

Note. * Equivalent letters for the same column do not differ at the level of significance $(\mathrm{p}<0.05)$ by means of the Tukey test. ** Values in parentheses and in italics represent the standard deviation of the sample.

The stemflow recorded much lower volumes, with the accumulated total of $14.5 \mathrm{~mm}$, which represents only $0.8 \%$ of the incident precipitation. Unlike the other rain partitions, the highest indexes were for the months of March, September, October and December, and did not differ statistically from one another.

The mean canopy interception was $8.9 \%$. During the warmest 3 months the average interception was $12.3 \%$, however, in the months representing autumn, the average interception by the canopies was only $5.4 \%$. The explanation for this variation is possibly due to the degree of closure of the canopy. Before starting the season with milder temperatures, abscission of some of the leaves occurs, due to the greater shading and lower solar radiation, intercepting less amount of the incident rainfall.

Among the climatic variables, the one that most influenced the canopy interception was the sum of days without rain in the month with a negative correlation of $71 \%$ and probability of error of $0.8 \%$. Then, the mean wind speed $(\mathrm{m} / \mathrm{s})$ was $66 \%$ and probability of error of $2.8 \%$. Table 2 shows the pearson correlation between the intercept by the crown and the climatic variables.

Table 2. Pearson correlation between climatic variables and canopy interception

\begin{tabular}{lllllll}
\hline & \multicolumn{5}{c}{ Climatic variable } \\
\cline { 2 - 6 } & EVT & Drought & Precpitation & Maximum Temperatur & Medium Temperatur & Minimun Temperatur \\
\hline Canopy Int. & 0.36 & $\mathbf{- 0 . 7 1 9}$ & $\mathbf{0 . 6 3 1}$ & 0.304 & 0.373 & 0.438 \\
Significance & ns & $\mathbf{0 . 0 0 8}$ & $\mathbf{0 . 0 2 8}$ & ns & ns & ns \\
\hline & Wind & Solar Radiation & Relative humidity & Relative humidity & Dew & Dew \\
Canopy Int. & $\mathbf{0 . 6 6 5}$ & 0.325 & -0.322 & 0.192 & 0.323 & 0.272 \\
Significance & $\mathbf{0 . 0 2 5}$ & ns & ns & ns & ns & ns \\
\hline
\end{tabular}

Note. $\mathrm{ns}=$ not significant; EVT $=$ evapotranspiration .

Climatic variable source: AGRITEMPO (2018).

Sadeghi et al. (2018) evaluated the dynamic interception of the incident precipitation and found a variation between 19 and 64\% with the species Robinia pseudoacacia during the stage of leafless and full-leaf respectively. The authors also observed variation with the species Platanus orientalis (22 and $47 \%$ ) for the same foliar stages respectively.

The regression analyzes for throughfall, stemflow and canopy interception as a function of the incident precipitation indicated an adjustment $\mathrm{R}^{2}=0.99 ; 0.89$ and 0.52 , respectively (Figure 3 ). The coefficients of 
variation had the following adjustments: $\mathrm{R}^{2}=0.56$ and 0.63 for throughfall and stemflow, that is, the volume increase decreases the standard deviation and, consequently, the coefficient of variation. The throughfall did not show an adjustment with increased rain volume, and the CV (\%), remained constant and with low adjustment, $\mathrm{R}^{2}$ $=0.06$. For Sari et al. (2016), the adjustment of the throughfall and canopy interception as a function of the incident precipitation was very similar, $\mathrm{R}^{2}$ of 0.88 and 0.56 in a Eucalyptus grandis stand at 3 years of age.

Balieiro et al. (2007) studied the behavior of rainwater after interaction with the Eucalyptus grandis canopy, and found very similar adjustments, $\mathrm{R}=0.99$ and 0.89 for the throughfall and stemflow respectively. $78.5 \%$ of the rainfall reached the forest floor and $15.6 \%$ of the rain was intercepted by the canopy. The highest volumes intercepted when compared to this study are mainly related to planting density, with approximately 3333 of Eucalyptus grandis versus 1430 plants ha $^{-1}$ of Eucalyptus dunnii respectively.

Studying the partition of rainwater in Eucalyptus pellita from the second to the sixth year Supangat et al. (2012) found rates of 3.8; 80.7 and $15.4 \%$ and coefficients of determination $\left(\mathrm{R}^{2}\right)$ of $0.77 ; 0.99$ and 0.29 for stemflow, throughfall and canopy interception, respectively. Possibly the values found are related to the highest number of trees per hectare, consequently, reducing throughfall and increasing the rate of canopy interception. Other studies also found a linear fit in the regression for throughfall as a function of the incident precipitation, being 0.9 for Gasparoto et al. (2014) and 1.0 for Li et al. (2015).
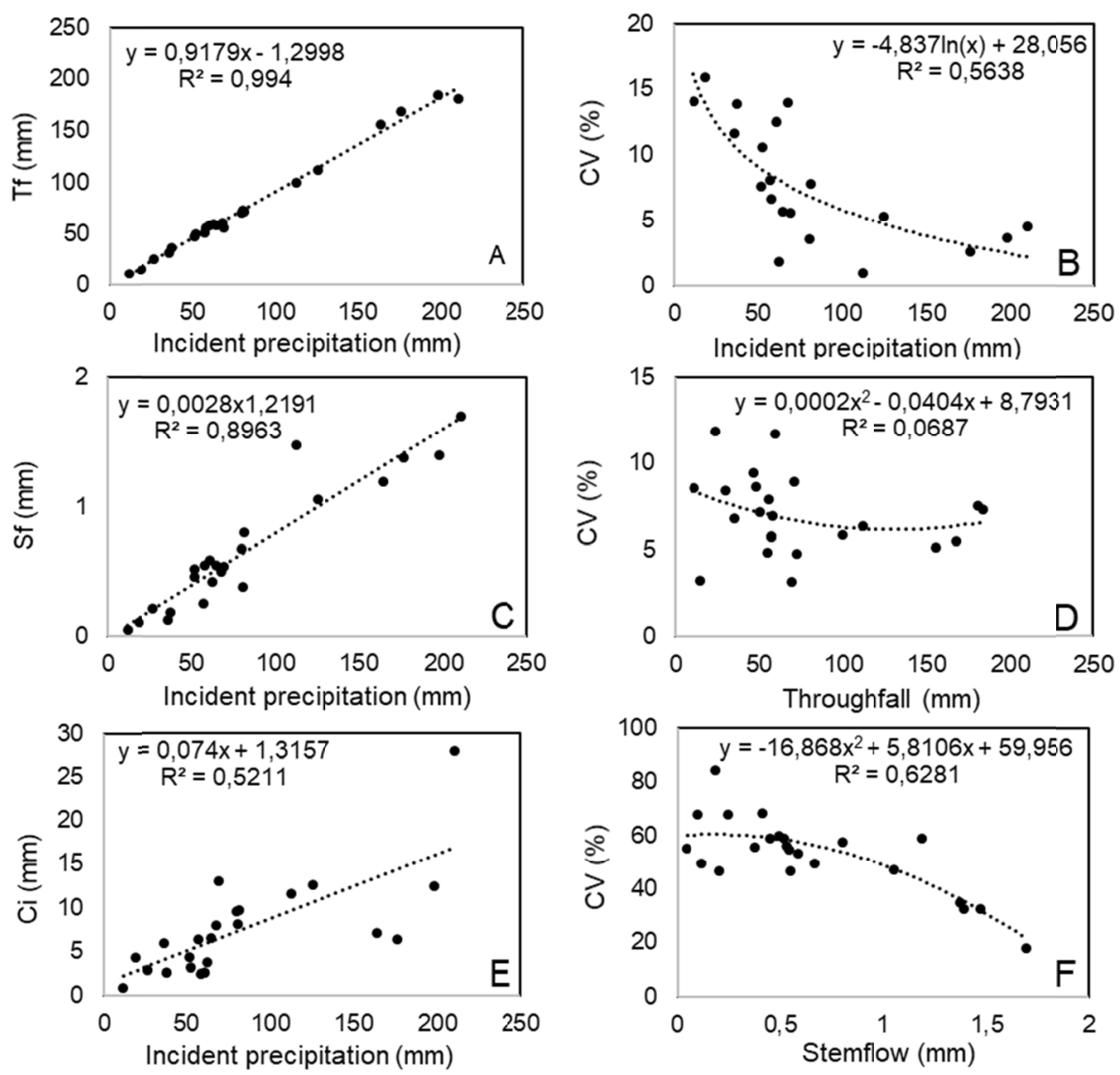

Figure 3. Relation of throughfall (A); stemflow (C); and canopy interception (E), as a function of incidente precipitation. Relationship of the coefficient of variation CV (\%) as a function of the amount of incidente precipitation (B); throughfall (D) and stemflow (F)

The graphical distribution of the residues was homogeneous and around the mean zero. It also shows that there is no bias. In Figure 4 we observed the distribution of the residues for throughfall, stemflow and canopy interception. 

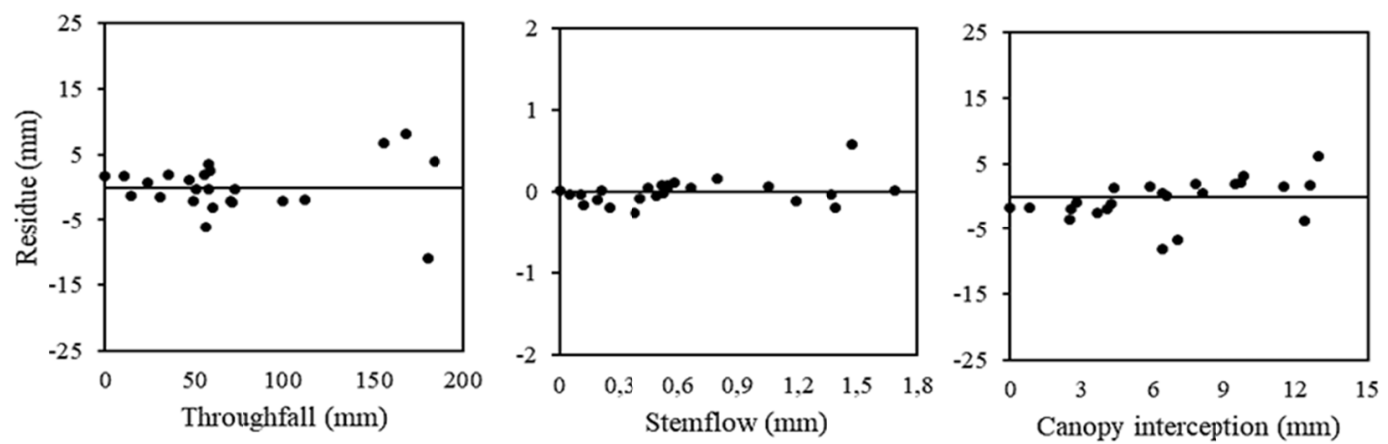

Figur 4. Graphical distribution of the regression residuals for throughfall, stemflow and canopy interception

The results found in the present study also reinforce that as the volume increases, the coefficient of variation decreases, especially when we refer to the stemflow. The forest canopy is quite heterogeneous and varies according to the spatial distribution of the collectors, degree of crown closure, tree spacing, faults and when we refer to the stemflow, the diameter of the chest and the presence of branches and branches, directly influence water quantification (Xiao \& Mcpherson, 2011).

According to Anna and Jaroslaw, (2014), the bark is an important factor in the development of the intercept coefficient. The authors concluded that there is a distinction between the bark intercept coefficient for different species and ages. These coefficients can be used in models to estimate hydrological processes.

Evaluatingthe canopy interception of native forests and exotic plantations with conifers and eucalyptus trees in Chile, Soto-Schönherr and Iroumé (2016) showed that native forests intercept about 50\% more rainwater than exotic species for the same DBH and basal area. The amount of rain that crosses the canopy of exotic plantations and reaches the litter layer is higher compared to the native forest. The reason that native forests intercept more water than tree plantations is a result of the degree of closure of the canopy. The canopy of commercial plantations are less dense, moreover, they are homogeneous and are basically single-storied.

Siegert et al. (2016) evaluated the factors that cause variability of throughfall and canopy interception in temperate deciduous forest installed in different topographic faces and showed that during the green season, the throughfall was reduced by $13.2 \%$ and $12.1 \%$ in the northern faces and east of the topography, presenting statistical differences, however, in the flat area the reduction was only $4.3 \%$.

Dunkerley (2014) in a study developed in the laboratory showed that a set of factors influence the amount of stemflow water, among them, the intensity of rainfall and its variation in time. In addition, the stemflow tends to be larger when the peaks occur at the beginning of the rain. Another aspect is how much the season of the year, the authors explain, that during the senescence period, the water flows more easily, nevertheless, during more intense events, there is the detachment of the water, mainly when the branches are longer.

In a Eucalyptus urophylla stand of 30-year-old in the municipality of Cunha-SP, distant 15 kilometers straight from the coast of the sea Arcova et al. (2018) evaluated the partition of rainfall over 3 years. The authors found good adjustments with linear equations $\mathrm{R}^{2}$ of 0.99 and 0.70 for internal precipitation and flow through the trunk respectively.

\section{Conclusions}

The linear regression of the throughfall, stemflow and canopy interception as a function of the incident precipitation, presented adjustments of $99 \%, 90 \%$ and $52 \%$. In addition, the analysis of the graphical distribution of the residues showed homogeneous behavior around the mean zero and without bias.

As the volume of rainfall increases, the coefficient of variation decreases. The annual rainfall was $1903 \mathrm{~mm}$, with a canopy interception average of $8.9 \%$. The climatic variables wind speed and days without rain partially explain canopy interception.

The throughfall was $1718 \mathrm{~mm}$ and the stemflow was $14.5 \mathrm{~mm}$. Considering the sum of these values, the net precipitation was $91 \%$ of the incident precipitation.

Although incident precipitation was homogeneous throughout the months of the year, the highest rainfall was observed in September. There was statistical difference at $5 \%$ probability of error, showing that the precipitation is seasonal. 


\section{Acknowledgements}

The first author thanks the Coordination for the Improvement of Higher Education Personnel (CAPES) for the scholarship.

\section{References}

AGRITEMPO. (2018). Dados meteorológicos-Alegrete. Campinas. Retrieved from http://www.agritempo. gov.br

Alvares, C. A., Stape, J. L., Sentelhas, P. C., Gonçalves, J. L. M., \& Sparovek, G. (2014). Köppen’s climate classification map for Brazil. Meteorologische Zeitschrift, 22(6), 711-728. https://doi.org/10.1127/09412948/2013/0507

Anna, I., \& Jaroslaw, K. (2014). Hydrological properties of bark of selected forest tree species. Part I: the coefficient of development of the interception surface of bark. Trees, 28, 831-839. https://doi.org/10.1007/ s00468-014-0995-0

Arcova, F. C. S., Ranzini, M., \& Cicco, V. (2018). Partitioning of rainfall in experimental plantations of Eucalyptus urophylla and Pinus elliottii. Floresta, 48(3), 383-392. https://doi.org/10.5380/rf.v48i3.55492

Balieiro, F. C., Franco, A. A., Fontes, R. L. F., Dias, L. E., Campello, E. F. C., \& Faria, S. M. (2007). Evaluation of the throughfall stemflow nutrient contents in mixed and pure plantations of Acacia mangium, Pseudosamenea guachapele and Eucalyptus grandis. Revista Arvore, 31(2), 339-346. https://doi.org/ 10.1590/S0100-67622007000200017

Bouillet, J. P., Laclau, J. P., Arnaud, M., M'Bou, A. T., Saint-André, L., \& Jourdan, C. (2002). Changes with age in the spatial distribution of roots of Eucalyptus clone in Congo. Forest Ecology and Management, 171, 43-57. https://doi.org/10.1016/S0378-1127(02)00460-7

Bulcock, H. H., \& Jewitt, G. P. W. (2012). Field data collection and analysis of canopy and litter interception in commercial forest plantations in the KwaZulu-Natal Midlands, South Africa. Hydrology Earth System Science, 16(10), 3717-3728. https://doi.org/10.5194/hess-16-3717-2012

Calder, I. R. (1999). Dependence of rainfall interception on drop size a replay to the comment by Uijlenhoet and Sticker. Journal Hydrology, 217, 164-165. https://doi.org/10.1016/S0022-1694(99)00003-7

Carlyle-Moses, D. E., Lishman, C. E., \& Mckee, A. J. (2014). A preliminary evaluation of throughfall sampling techniques in a mature coniferous forest. Journal of Forestry Research, 25(2), 407-413. https://doi.org/ $10.1007 / \mathrm{s} 11676-014-0468-8$

Chaffe, P. L. B., Kobiyama, M., Yamashiki, K., \& Takara, K. (2010). Is interception information important for rainfallrunoff modeling? Ann. J. Hydraulic Eng., 54, 73-78.

Dick, G., Schumacher, M. V., Momolli, D. R., \& Viera, M. (2018). Nutrient Input via Incident Rainfall in a Eucalyptus dunnii Stand in the Pampa biome. Floresta Ambiente, 25(3). https://doi.org/10.1590/21798087.055916

Dunkerley, D. (2014). Stemflow production and intrastorm rainfall intensity variation: An experimental analysis using laboratory rainfall simulation. Earth Surf. Processes Landforms, 39(13), 1741-1752. https://doi.org/ 10.1002/esp. 3555

Fan, J. L., Oestergaard, K. T., Guyot, A., Jensen, D. G., \& Lockington, D. A., (2015). Spatial variability of throughfall and stemflow in an exotic pine plantation of subtropical coastal Australia. Hydrol. Process, 29, 793-804. https://doi.org/10.1002/hyp.10193

Flores, T. B., Alvares C. A., Souza V. C., \& Stape J. L. (2016). Eucalyptus no Brasil: Zoneamento climático e guia para identificação. Piracicaba: IPEF.

Gasparoto, E. A. G., Tonello, K. C., Shinzato, E. T., \& Valente, R. O. A. (2014). Throughfall in different forest stands of Iperó, São Paulo. Cerne, 20(2), 303-310. https://doi.org/10.1590/01047760.201420021260

Gerrits, A. M. J., \& Savenije, H. H. G. (2011). Interception. In W. Peter (Ed.), Treatise on Water Science (pp. 89-101). Oxford: Academic Press. https://doi.org/10.1016/B978-0-444-53199-5.00029-4

Hörmann, G., Brandig, A., Clemen, T., Herbst, M., Hinrichs, A., \& Thamm, F. (1996). Calculation and simulation of wind controlled canopy interception of a beech forest in Northern Germany. Agriculture and Forest Meteorology, 79(3), 131-148. https://doi.org/10.1016/0168-1923(95)02275-9

IBÁ (Indústria Brasileira de Árvores). (2017). Relatório anual 2017: Ano base 2016 (p. 80). 
IBM Corp. (2011). IBM SPSS Statistics for Windows, Version 20.0. Armonk, NY: IBM Corp.

Jackson, R. B., Jobbagy, E. G., Avissar, R., Roy, S. B., Barret, D. J., Cook, C. W., ... Murray, B. C. (2005). Trading water for carbon with biological carbon sequestration. Science, 310, 1944-1947.

Johnson, M. S., \& Lehmann, J. (2006). Double-funneling of trees: Stemflow and root-induced preferential flow. Ecoscience, 13, 324-333. https://doi.org/10.2980/i1195-6860-13-3-324.1

Keim, R. F., Skaugset, A. E., \& Weiler, M. (2006). Storage of water on vegetation under simulated rainfall of varying intensity. Advences in Water Resources, 29, 974-986. https://doi.org/10.1016/j.advwatres.2005. 07.017

Levia, D. F., \& Frost, E. E. (2006). Variation of throughfall volume and solute inputs in wooded ecosystems. Progress in Physical Geography: Earth and Environment, 30, 605-632. https://doi.org/10.1177/03091333 06071145

Levia, D. F., Van Stan, J. T., Mage, S. M., \& Kelley-Hauske, P. W. (2010). Temporal variability of stemflow volume in a beech-yellow poplar forest in relation to tree species and size. Journal of Hydrology, 380, 112-120. https://doi.org/10.1016/j.jhydrol.2009.10.028

Li, Y. (2015). Canopy interception loss in a Pinus sylvestris var. Mongolica forest of Northeast China. Journal of Arid Land, 7(6), 831-840. https://doi.org/10.1007/s40333-015-0013-4

Lima, W. P. (1976). Interceptação da chuva em povoamento de eucalipto e de pinheiro. IPEF, 13, 75-90.

Llorens, P., Domingo, F. (2007). Rainfall partitioning by vegetation under Mediterranean conditions: A review of studies in Europe. Journal of Hydrology, 335, 37-54, https://doi.org/10.1016/j.jhydrol.2006.10.032

Mululo Sato, A., Souza Avelar, A., \& Coelho Netto, A. L. (2011). Spatial variability and temporal stability of throughfall in a eucalyptus plantation in the hilly lowlands of southeastern Brazil. Hydrological Processes, 25, 1910-1923. https://doi.org/10.1002/hyp.7947

Navar, J. (2011). Stemflow variation in Mexico's northeastern forest communities: Its contribution to soil moisture content and aquifer recharge. Journal of Hydrology, 408(1), 35-42, https://doi.org/10.1016/ j.jhydrol.2011.07.006

Reichert, J. M., Rodrigues, M. F., Peláez, J. J. Z., Lanza, R., Minella, J. P. G., Arnold, J. G., \& Cavalcante, R. B. L. (2017). Water balance in paired watersheds with eucalyptus and degraded grassland in Pampa biome. Agricultural and Forest Meteorology, 237-238, 282-295. https://doi.org/10.1016/j.agrformet.2017.02.014

Sadeghi, S. M. M., Van Stan, J. T., Pypker, T. G., Tamjidi, J., Friesen, J. \& Farahnaklangroudi, M. (2018). Importance of transitional leaf states in canopy rainfall partitioning dynamics. European Journal of Forest Research, 137(1), 121-130. https://doi.org/10.1007/s10342-017-1098-4

Salehi, M., Zahedi Amiri, G., \& Attarod, P. (2016). Seasonal variations of throughfall chemistry in pure and mixed stands of Oriental beech (Fagus orientalis Lipsky) in Hyrcanian forests (Iran). Annals of Forest Science, 73, 371-380. https://doi.org/10.1007/s13595-015-0525-2

Sari, V., Paiva, E. M. C. D., \& Paiva, J. B. D. (2016). Interceptação da chuva em diferentes formações florestais na região sul do Brasil. RBRH, 21(1). https://doi.org/10.21168/rbrh.v21n1.p65-79

Savenije, H. H. G. (2004). The importance of interception and why we should delete the term evapotranspiration from our vocabulary. Hydrol. Processes, 18(8), 1507-1511. https://doi.org/10.1002/hyp.5563

Siegert, C. M., Levia, D. F., Hudson, S. A., Dowtin, A. L., Zhang, F., \& Mitchellet, M. J. (2016). Small-scale topographic variability influences tree species distribution and canopy throughfall partitioning in a temperate deciduous forest. Forest Ecology and Management, 359, 109-117. https://oi.org/10.1016/ j.foreco.2015.09.028

Soto-Schönherr, S., \& Iroumé, A. (2016). How much water do Chilean forests use? A review of interception losses in forest plot studies. Hydrological Processes, 30, 4674-4686, https://doi.org/10.1002/hyp.10946

Staelens, J., De Schrijver, A., Verheyen, K., \& Verhoest, N. E. C. (2006). Spatial variability and temporal stability of throughfall water under a dominant beech (Fagus sylvatica L.) tree in relationship to canopy cover. J. Hydrol., 330, 651-662. https://doi.org/10.1016/j.jhydrol.2006.04.032

Sulinski, J., Starzak, R., \& Kucza, J. (2001). Weryfikacja wzoru wyra zajacego intercepcje drzew w zaleznosci od nate zenia i czasutrwania opadu deszczu w warunkach eksperymentalnych. Acta Agraria et Silvestria, 39, $3-16$. 
Supangat, A. B., Sudira, P., Supriyo, H., \& Poedjirahajoe, E. (2012). Study of Rainfall Interception at Eucalyptus pellita Plantation Forest in Riau. Agritech, 32(3), 318-324.

Thomaz, E. L., \& Antonelli, V. (2015). Rain interception in a Secondary fragment of Araucaria forest with faxinal, Guarapuava-PR. Cerne, 21(3), 363-369. https://doi.org/10.1590/01047760201521031736

Xiao, Q., \& Mcpherson, E. G. (2011). Rainfall interception of three trees in Oakland, California. Urban Ecosystems, 14, 755-769. https://doi.org/10.1007/s11252-011-0192-5

Zhang, Y., Wang, X., Pan, Y., \& Hu, R. (2016). Variations of Nutrients in Gross Rainfall, Stemflow, and Throughfall Within Revegetated Desert Ecosystems. Water Air Soil Pollution, 227(6), 183. https:/doi.org/ $10.1007 / \mathrm{s} 11270-016-2878-\mathrm{z}$

Zimmermann, A., Wilcke, W., \& Elsenbeer, H. (2007). Spatial and temporal patterns of throughfall quantity and quality in a tropical montane forest in Ecuador. Journal of Hydrology, 343, 80-96. https://doi.org/10.1016/ j.jhydrol.2007.06.012

Zimmermann, A., \& Zimmermann, B. (2014). Requirements for throughfall monitoring: The roles of temperate scale and canopy complexity. Agricultural and Forest Meteorology, 189-190, 125-139. https://doi.org/ 10.1016/j.agrformet.2014.01.014

\section{Copyrights}

Copyright for this article is retained by the author(s), with first publication rights granted to the journal.

This is an open-access article distributed under the terms and conditions of the Creative Commons Attribution license (http://creativecommons.org/licenses/by/4.0/). 